\title{
Conceptualising teachers' advocacy as comedic trickster behaviour: Implications for teacher education
}

\author{
Mary Rice \\ University of Kansas \\ mary.rice@ku.edu

\section{Brian Rice} \\ University of Kansas \\ brianjoerice@ku.edu
}

\begin{abstract}
The conception of a comedic hero as a trickster functions as a useful trope for evaluating the attempts teachers make as advocates in schools. The specific elements of the trope that the authors find useful are (a) comedy as a space where the absurd mingles with the tragic; $(b)$ resurrection or bringing forward from the dead as major plot device; and (c) the goal of societal integration. These elements of the comedic trickster trope are used to interpret three narratives of teacher advocacy in a junior high school. By analysing these narratives of advocacy in the frame of the comedic trickster, the authors argue that current teacher education practices described in research literature provide little guidance for how teacher candidates moving into school systems can develop and proactively maintain a stance of advocacy in their interactions with students and colleagues. Teacher candidates are not being prepared to handle absurdity, tragedy, resurrection, or the integration of students. Further, the authors assert practicing teachers who engage in advocacy in the frame of a comedic trickster are in danger of succumbing to an ironic plotline where they are unable to do what they want to and know they should. Acknowledging the presence of comedic tricksters might open up spaces for practicing teachers to write new stories of themselves as advocates and avoid the entrapment of irony.
\end{abstract}

Keywords: advocacy, teacher education, comedic trickster. 


\section{Conceptualising teachers as advocates}

The fact that students and their families generally have little decision making power in schools can no longer be ignored (Baquedano-López et al. 2013). In order to mitigate this power imbalance, there are increasing calls for teachers to act as advocates for all students (Kelly 1986; Zeichner 2003), but especially for students who have been traditionally denied full participation in school contexts (Barolomé 2004; Roberts \& Siegel 2012). At first blush, one might wonder why teachers are charged with the duty to advocate. Advocacy is a term rooted in the legal profession where the goal is to use rhetoric to argue for an interpretation of law or policy (Hanraha 2003). The idea that the teacher is the ideal person to be an advocate stems from the perception that teachers live with the students day after day doing the work of planning, teaching, and assessing. This reality positions them to build relationships with the children and their families and gives them perspective on how school policies and ways of being impact individual children. In the legal profession, advocating for both sides would represent a massive conflict of interest, but in education this is a much taken for granted, unquestioned position in which teachers find themselves.

However, institutions employ teachers and so they are charged to represent institutional interests (Kelly 1986). Thus, the idea of advocacy from the perspective of power is somewhat of a double-edged sword. One blade cuts in the direction of teachers who do not speak up about the way in which policy impacts children and families because they fear the institution and so they are perceived as weak or ineffectual by the institution and the community. The other blade cuts in the direction of teachers who represent children and families' and are rebuked by the institution or community for doing so. Living under this double threat can be challenging for teachers to attend to because as the sociologist Willard Waller (1932) observed, teachers must strive to please the institution and the community or they become cynical and leave the profession. In sum, while it is received wisdom that teachers should represent students and families to the institution and represent the institution to students and parents, there is little understanding about how teachers actually do this in practice. If more was known about teachers' understanding of advocacy in practice, those understandings could play a crucial role in sustaining them in their work.

\section{Proposing the studying of advocacy as comedic narratives}

These tensions embodied in the double-bind (Engeström 2001) of advocacy also appear in the study of narrative (Fisher 1984) as comedic experience. Comedy has a literary meaning that often involves humour as characters are put in awful situations and have to use their cunning to affect a resolution. Narrative structures are particularly helpful in advocacy discussions not just for the closeness between real-life tension and literary conflict, but also for the causal relationships that exist in both spaces that result in a plot or tightly interwoven events. For these reasons, narrative is an ideal site for studying events like advocacy events, which have multiple cause/effect patterns that drive the plot.

In this article, we take up two ideas from narrative theory: that of comedy and that of the trickster. In literature, a comedy is more than a story that makes you laugh. Frye (2002) explains that comedy appears in two forms: the social and individual. Through the experience of humour comic relief is achieved. This in turn acts to free the individual from a humorous society and society from the bonds produced by humorous individuals. The result is so ludicrous that laughter is a likely result. Comedy, whether resulting directly from humour and accompanied by laughter 
or not, can also act to integrate society and community (Frye 1957). In this way the humour produced by the comedic acts of the educator can act to both integrate and separate individuals and society.

Tricksters in literature appear as a god, goddess, spirit, man, or woman that disobeys conventional patterns of behaviour (Hansen 2001). The incidences when the educator, acting as trickster, breeches social etiquette can be compared to tricks. The rules that are broken in the playing of tricks are important because they are the rules of the gods; in the case of an educational setting, the local area authority recognised as the principal would represent the authority figure. In ancient and more contemporary stories breaking rules can have positive effects (e.g., Mordecai's refusal to bow before Haman in the Bible, Robin Hood's theft from the rich to redistribute to the poor, Rhea's not feeding Zeus to Cronos in Greek mythology) rather than negative ones (e.g., Cain's murder of his brother Abel in the Bible, the misfortunes of Karna in Hindu mythology, the Native American folktale of the badger and the bear, Icarus' defiance of his father in Greek mythology). As we read about both comedy in literature and tricksters in mythology, we became aware of the overlap between these conceptions with advocacy in schools. We saw the places where we had to act in unexpected ways to create comedy where humour was a frame that often emerged. When we told these stories outside of humour, our audiences responded with incredulity and even anger - two responses that do not usually promote community building.

The trickster figure appears as part of multiple cultures and traditions (Wyatt 2005; Priyadharshini 2012). The trickster as archetype appears as animals such as the coyote and raven in Native American narratives, Loki in Norse narratives, and Heres in Greek narratives. The teacher, in the role of trickster's, exercises shapeshifting ability to become educator, advocate, and loyal employee as the situation requires. It is within these acts of shapeshifting that humour emerges. These teacher's transformations separate them as individual from their society, but also position them to have a certain kind of moral authority.

According to Priyadharshini (2012), the trickster attempts to introduce communication where none exists. The comedic trickster's roles as advocate and loyal employee act to both separate the individual from society and confirm their place within society. The humour exists within the tensions constructed by the act of being apart from and a part of the social group be that group the oppressed, students and their families, or the oppressor, policy makers and administrators. Comic resolution occurs through the individual release and social reconciliation (Frye 2002).

It is with these understandings about comedy that we propose the conception of a comedic trickster as a useful metaphor for describing the attempts teachers make to advocate for students and their families in schools. This article reviews literature on advocacy among practicing teachers in schools and then makes firm connections between research on advocacy and the role of comedic tricksters. It also details our process of taking a critical look at our own attempts to advocate in the school where we worked that offer insight into our conceptualisation of a comedic trickster as an advocate on the educational landscape. The specific aspects of the metaphor that we found useful are (a) comedy as an integrating force operates in a space where the absurd mingles with the tragedy as an event of separation; (b) resurrection or rejoining society as a major plot device; and (c) societal integration mediated by rule-breaking and critique. 


\section{Providing background and context for linking advocacy and comedic tricksters}

We have been married for almost 13 years. After we met and married, we both entered teacher certification programmes and were hired by the same school district in the United States. Brian's initial teaching position was in the special education department, working in a self-contained unit for elementary students with emotional and behavioural disorders. Due to district space constraints, this unit was headquartered at a local junior high. It was at this same junior high that Mary was offered a position teaching English learners and general education language arts. After one year, the unit Brian was working in dissolved and the principal of our junior high offered him a position teaching resource language arts to students with mild to moderate specific learning disabilities.

In the years since arriving first unofficially and then officially at the same school, both of us gradually increased our responsibilities there. Brian accepted the duty of coaching boys' and girls' tennis afterschool, where he interacted with students from across multiple age and school achievement ranges, was the association representative, and on occasion ran part of an after school intramural athletic program. Mary was the alternative languages specialist, where she taught the English as a second language class, oversaw placement of English learners, and structured learning plans for these students. She also taught language arts classes for underachieving reading, general education, and honours students. Both of us had mentoring responsibilities at our school and Brian had mentoring responsibilities with the district. Mary mentored practicum students at a local university. In the past, she had also been assigned new teachers to mentor. Brian worked with Special Education teacher mentoring.

In addition to our work at the junior high, we both had responsibilities as teacher educators at a nearby university's endorsement programme for certifying teacher candidates to work with English learners. Brian's work at the university focused on meeting the needs of students who are both English learners and have various disabilities as well as assessment for English learners in general. Mary's work focused on aspects of language acquisition, constructing curriculum for content, language, and literacy development, and family involvement policies and practices in schools.

We became interested in conducting a study about advocacy as we started to have conversations about the meaning of advocacy for teachers in conjunction with the multiple roles we had both taken on in schools. These conversations emerged from our work with teacher candidates and novice teacher mentees in trying to encourage and prepare them to advocate. In order to gain some understanding for our questions, we designed a self-study of our teacher education practice so we could explore what advocacy looked like for us in our junior high setting in the context of ethical relationships with both young people and teachers. Our ultimate goal for this study was to sharpen our focus in encouraging and preparing the teacher candidates at the university and novice teacher mentees at our school to assume identities as advocates. Instead of merely asserting advocacy is important, we sought to explore our own efforts to be advocates.

\section{Reviewing literature about advocacy}

Before we delve more deeply into the comedic trickster as a metaphor for advocacy, we will discuss definitions of advocacy in previous research studies. The major conceptualisations put 
forward in the professional literature are: advocacy as meeting needs; advocacy as social capital; advocacy as student learning.

\subsection{Defining advocacy as meeting needs}

According to Howe (1986), advocacy occurs when adults in schools fulfil their responsibility to ensure that the needs of all children as well as individual children are met, independent of social attitudes or current political factions. From our perspective, this definition assumes that school officials have a responsibility to advocate. Through well-executed advocacy, the needs of all students can be met successfully and those needs could be stripped of context, meaning that advocacy could be viewed as a prescriptive process (if $x$ occurs, respond with $y$ behaviour).

In another study, Catapano (2006) uses a service-learning model to help teachers explore issues of social justice. These teacher candidates completed a full year of field experiences in an urban classroom. They were taught several advocacy strategies that were built around the idea of advocacy as meeting needs. The teacher candidates were expected to use them in their contexts. The strategies were: (1) recognising issues that impact families and children; (2) taking the perspective of those who are impacted; and (3) looking for solutions within the context of the classroom. These strategies were reported to help pre-service teachers see themselves as possible agents of systemic changes in schools as they became classroom teachers. Catapano argues that reflections with the teacher candidates on how to blend the strategies of service-learning, mentoring, advocacy development, and teacher education lead directly to the development of a more integrated model of teacher education.

We select this definition of advocacy as meeting needs initially because of its broad orientation and because we support the perspective that what school officials do can, in fact, affect students in positive ways. However this definition is also problematic to us because our years in public schools working with students from diverse backgrounds had taught us that the needs of all the children rarely, if ever, get met and that political and social milieus have tremendous influence on how decisions are made in schools.

\subsection{Defining advocacy as social capital}

Under Howe's (1986) definition, it is unlikely that advocacy can exist in a practical sense in schools. Rice (2009) described this problem when she realised that the definition of advocacy she used required her to constantly be unsatisfied with herself, her school, and her community. In order to avoid becoming completely disillusioned in her work, she adopted a definition of advocacy where other people had agency and could choose whether to reciprocate social capital (Putnam 2001). This comedic tension coincides nicely with Frye's (2002) definition of comedy as a device that allows humour to lead to reconciliation. As Rice assumes the form of trickster attempting to play the part of both the advocate for students and a loyal employee, she finds herself in laughable situations.

Our work is also informed by the assertions of Buendía (2000), who argues specifically for practical knowledge of advocacy for diverse children. According to Buendía, it is problematic to instil advocacy in teacher preparation programmes in general because it is difficult for universities to gain access to the landscape of school at the level necessary, as well as garner the time commitment in teacher preparation sufficient to lead toward individual growth. This orientation to advocacy is relational. A person gains strength as an advocate by forming strong ties to the 
community wherein the school resides. Nonetheless, there are some teacher education programmes that claim various levels of success in helping teacher candidates learn to advocate. Athanases \& Oliveira (2007) found a programme at their university that focuses on helping the teachers develop relationships with the students and encourages them to start after school programmes and clubs that appeal to English learners and diverse students in general had a high percentage of graduates who indicated that they were prepared to do those things when they graduated. Some teachers even stated that they were able to enact advocacy in these ways at the schools where they were hired. Building relationships and hosting activities are ways of building social capital (Putnam 2001) that seems distant from Howe's (1986) call to meet all the needs. Such skills position teachers to have access to student voices that could potentially help them to learn of and meet current needs.

Generally teachers do not feel supported in their efforts to advocate, especially when they are new to the school landscape in general as well as the particular landscape where they were hired. In a study by Norquay \& Robertson-Baghel (2011), four teacher candidates were followed three years into their induction. There participants found it difficult to advocate when faced with administrative and institutional pressures, although they left their teacher education programmes with a desire to advocate. These researchers ended the report of their research by recommending that new teachers receive both invitation and permission to use the desire to advocate during teacher education programmes.

It is not known whether the lack of access to the school landscape in the form of permission and support is a contributing factor in the new teachers' feelings of vulnerability that Athanases \& Oliveira (2007) describe. The new teachers in their study found themselves complying with the dominant values of the school, rather than their own desires to inculcate increased fairness and protect the more vulnerable children from harm. Without the identity of trickster new teachers cannot shapeshift from educator to advocate and any progress toward comedy is stunted without humour or victory (Frye 2002). The new teachers in this study reported a "fear of getting in trouble" (Athanases \& Oliveira 2007: 129) and a "risk of job loss as [being] too great" (Athanases \& Oliveira 2007: 130) to advocate for children. These fears may be symptoms of a lack of social capital (Putnam 2001) with their colleagues. These new teachers reported feeling ill prepared to "manage confrontation with other educators when conflicts [arose] regarding issues of equity" (Athanases \& Oliveira 2007: 133).

\subsection{Defining advocacy as student learning}

Issues of job risk compete with what Athanases \& Martin (2006) claim, that student learning is the purpose of advocating for educational equity. This is much more specific than the general call for the adults to meet the needs of the children that Howe (1986) recommends. The use of student learning as the standard seems easier to meet. As long as the students are learning, teachers can feel like they are advocating. Humour emerges as the teacher believes they can directly equate student learning with student advocacy without involving the shapeshifting abilities of the trickster. The complicated and humorous aspects of this definition continue as teachers consider what the students might be learning. If agreement could be reached on what should be learned, that next question would ask what would count as proof of learning.

Athanases \& Martin's (2006) argument that student learning is advocacy seems removed from Athanases \& Oliveira's (2007) work in helping teacher candidates employ advocacy through relationship building and social interaction. Are diminishing negative social behaviours or interest in the curriculum proof of student learning? Do they support student learning? Riley (2011) 
reported that positive student-teacher relationships lead to positive outcomes for students based on a review of literature that he conducted, but he does not say whether those outcomes constitute learning specifically.

Since new teachers have been cited as needing assistance in things like instructional design and classroom management (Brophy \& Good 1997), they are often unprepared to focus on student learning in the same ways that a teacher with more experience might be able to. Focusing on student learning may also be a struggle for new teachers and teacher candidates because they are often young adults who are still in the phase of developing their own identity. A consequence of their development is that they are still highly self-focused as they move from trying to achieve identity to trying to achieve the capacity for intimacy (Erikson 1994). Developing such capacity could be strengthened through engaging in the types of relational advocacy that Athanases \& Oliveira (2007) worked to instil in their teacher candidates. However, doing so could also be more difficult for new teachers since they may have a limited capacity for doing so initially even if they develop new understandings, as Norquay \& Robertson-Bahgel's (2011) teacher candidates did. Since novice teachers and teacher candidates, regardless of age, are naturally highly selfconscious and self-focused, it makes sense that they would develop and express feelings of being forced to decide between advocating for students on their own terms and continuing to be employed and achieving tenure. Each of these goals places the needs of the teacher ahead of those of the children. Thus, new teachers may be focused on advocating for themselves first, which is the act of a true trickster.

\section{Confronting the perceived lack of advocacy in schools}

While we were able to find a handful of studies that focused on helping teacher candidates develop advocacy dispositions and skills, a search of the professional research literature uncovered no studies of advocacy among tenured practicing teachers. It is unknown whether tenured teachers have the same fears as new teachers do pertaining to job security. We jokingly speculated that the dearth of research in this area might be based on either the assumption that practicing teachers do not engage in advocacy or that they enact advocacy perfectly. Our more serious rationale is that all of the problems Buendía (2000) described for studying advocacy among teacher candidates may be in force to a greater degree for practicing teachers since they have not been traditionally accountable to universities or other entities that insist on advocacy. Another concern for practicing teachers in terms of enacting advocacy may be that doing so may position them in opposition to the peer or building norms and certainly positions them in opposition to accountability systems that are gaining increasing momentum within their districts.

Another factor that may or may not be related to recent interests in racketing up accountability measures for teachers has to do with the current state of the American economy. Teaching has often been regarded in the United States as a safe career choice with stable wages and benefits that outweigh what is referred to as a slight discrepancy in pay between teaching and other careers commensurate with educational attainment and work experience. In the current economic downturn, more teachers are being laid off or fired under charges of inadequacy especially in highly impacted districts only to have money appear later for wealthier, more affluent areas (Vevea 2010). The public has also become increasingly disenchanted with the tenure system in public education, believing it to be a way for teachers to make them invulnerable to dismissal although teachers and teachers' unions staunchly contend such unwarranted protection does not exist (Walker 2010). 
Our review of the professional literature also revealed that discussions about advocacy are absent from the legislative and school governance landscapes, and do not appear in state or district level curriculum documents or directives that teachers have access to. Since these entities seem not to have space for advocacy, it makes sense that practicing teachers and researchers may not intentionally direct efforts towards examining it in such settings. We had both heard mantras of "let's do what's best for kids" from administrators at school and central office levels. These admonitions are often the result of efforts to convince us and our colleagues to do things that both of us felt would hurt students with disabilities, English learners, and other at-risk populations on both the meeting the needs of the students (Howe 1986) and promoting student learning (Athanases \& Martin 2006) standards of advocacy. Therefore, we are hesitant to call the request to "do what's best for kids" a call for advocacy that matches any definition that we were able to uncover in the research literature.

\section{Uncovering methods for examining trickster advocacy in our teaching}

The methods we used to consider the comedic trickster as a metaphor for advocacy were first aimed at learning about how we experienced advocacy and then conceptualising that advocacy through metaphor. In order to attend to the first part of our task, we determined that stories would serve as acceptable artefacts for documenting and explaining understandings about our research puzzle because we realised that stories were the typical mode for communicating our lived experiences with advocacy to the teacher candidates and novice teachers with whom we have worked. Support for the use of stories also comes from Clandinin et al. (2007). These researchers proposed a three-dimensional narrative space that can be used as an analytic tool for unpacking meaning in stories. A story placed in the three-dimensional space enables an inquirer to push on elements of temporality, examine the inward (personal) and the outward (social) nature of the narrative, and then allow the narrative to shift across various dimensions of time within a particular place or context. These dimensions of narrative form the basis for research design in narrative inquiry. We refer to our school context as a landscape, which is a concept from the work of Clandinin \& Connelly (1995).

The following section reveals the methods we employed in order to conduct a study on our work together as advocates for junior high students. Specifically, we will discuss the ways in which we gathered the stories of advocacy. After explaining how we gathered the data, we will discuss how we placed stories in the three-dimensional space for analysis.

\section{Gathering stories}

We collected the stories over the course of an academic school year. In order to do this, we each kept separate lists of stories that we thought demonstrated advocacy according to Howe's (1986) definition. At two points, mid-year and at the end of the year, we sat down together to relive and retell the stories we had gathered. At the end of the first conversation, we compiled a long joint list of stories. From these lists of our acts of advocacy, we analysed shared and unique features, from which we developed themes. Then, we met again to examine our list to verify that we agreed on our categorisation of our advocacy stories and that the stories fit into one of the themes that we developed during our first meeting for reliving and retelling. We then checked our categories with another researcher to verify our interpretation as being grounded in our stories. This practice is 
supported by the work of Loughran \& Northfield (1996) where Northfield engaged Loughran in a review of his data. In this way, we collected, sorted, analysed, and established trustworthiness for our data by checking with an expert.

\section{Analysing stories}

Our research purpose, which was the exploration of the ways in which we as practicing teachers used advocacy to meet student needs, was met when, after several rounds of reliving and retelling, patterns emerged. To us, these patterns conceptually resembled VENN diagrams. A VENN diagram shows all possible relations between different groups or sets. The shape of a VENN is two circles that overlap slightly. In the space of overlap, the similarities are placed. In the unshared space the differences are recorded. The most significant pattern was the VENN of shared advocacy. Using Clandinin \& Connelly's (1990) language, sometimes our individual plotlines competed; other times they conflicted, and still other times they were synchronous, thus a series of conceptual VENNs resulted.

\section{Interpreting stories}

The process of interpretation was untidy. Initially, we looked at the VENN diagrams that had resulted during our analysis and more stories came to our consciousness. We felt free to tell these stories and compare our tellings. Folklorist William Wilson (1990) suggested a concept called the family novel. According to Wilson, a family novel is a compendium of mostly oral stories told in families that bond the members. The family novel is read, meaning that stories are told in such a fashion that the existence of the novel is generally unknown to family members. When new people join that family, as in through marriage, or some other circumstance, they are acutely aware of the family novel. The new person realises that they have not read it, and therefore, does not understand the references the family members make to various chapters. The new person gradually learns the family novel and can reference it with the same ease as other members. As teachers, who are married to each other and work at the same school, we possess a family novel of the children that we work with. As we interpreted the stories in the VENNs, we metaphorically flipped back and forth to other chapters and came to agreements about what the novel said. This process was much like the process of text negotiation germane to the narrative inquiry methodology (Clandinin \& Connelly 2000), wherein we were both participants and researchers and so our interpretations have been filtered through both lenses.

Stories of shared advocacy occurred when both of us played a role in causing the advocacy to unfold. In the conceptual pattern common to a VENN, however, we also had instances of advocacy that were not shared. In these instances, it became evident that we each had a different plotline for enacting advocacy. Brian's plotline was built around a concern for what would be best for the entire school. Mary, however, had a plotline built around ethical obligations to individual students.

As we contemplated the VENNs and examined the stories, we realised that the metaphor of comedic trickster would suitably capture our findings. In order to test this metaphor, we reviewed Frye's (1957) explanation of literary modes and then we placed each of the stories in the cycle he described as moving from paradise to tragedy to irony to comedy. As the stories held the pattern we began to consider what we might call ourselves as we functioned as advocates. Frye's term 
would be hero. In Frye's paradigm, a hero is non-axiomatic: it does not carry connotative weight, but we realised that in popular culture, that is not the case and we were already planning to ask the audience of our work to reconsider the definition of comedy as social integration and not humour. Ultimately, we came to call ourselves tricksters because we felt that our acts described our roles more clearly than hero would have done both in a literary and a connotative sense. Using the term trickster also removed the sanctity embedded for many in the word hero.

\section{Revealing advocates as comedic tricksters}

According to Hansen (2001), the trickster's work is often socially inappropriate for the context. The trickster is willing to do the thing that is simply not done. In addition, there is often a better way to achieve a goal than a trickster chooses. Further, Tricksters derive their tricks from their cleverness and use keen observation of humankind or at least the humans in the contexts in which they live to decide what tricks to play. For us, those characteristics are the heart of advocacy behaviour. The three stories explored as representative findings in this article offer a glimpse into the ways in which we enacted trickster behaviour.

\subsection{Thinking about the trickster and the behavioural contract}

The most significant manifestation of advocacy as comedic trickster behaviour came together as a story about an English learner who was disruptive in the majority of his classes, making it difficult for others to learn. Since Brian is bilingual and has a history of advocating for English learners, the administrator assigned to work with this student solicited Brian's input. Brian recommended that the student be removed from the school since this student was on a visitor's contract because he did not live within our school boundaries. The contract, which the student and his parents signed, indicated that visiting status put him in a more precarious position when it came to behaviour and discipline. Mary agreed with the legality of the contract but thought it was unfair to expel the student so easily even through the contract he had signed made it easy to do so without much ado. Mary worried about the long-term consequences for this student, who would now have to bear the weight of being dismissed from an institution, especially as he tried to enter a new one. As our conflicting plotlines collided around this student unfolded, those plotlines entangled several more times until the student was eventually removed from our school for a period of time, but was eventually able to return.

During this incident, we were irritated with one another on several occasions. Our marriage made it necessary to make efforts to repair our working relationship. We have wondered if we would have reconciled so quickly if we had been merely colleagues and how disagreements involving advocacy might have resonated in our professional landscapes across time. We also wondered if either of us would have perceived the other's annoyance as pressure from the institution (Athanases \& Oliveira, 2007) to behave in a certain way if we had not known each other well and known that eventually we would both overcome our disagreement and be back for another round with the administrator if need be.

If comedy is a space where the absurd mingles with the tragic, surely this was an experience with that. To Mary, it was absurd that a student would be forced to sign a guest contract that did not include due process for dismissing him or her. The separation is the element that makes the event tragic in the literary sense. To Brian, it was absurd that Mary was so interested in due process since it seemed obvious to him that the student was going to be removed no matter what 
and so the best course of action was to be efficient. For Brian, the tragedy was brought on by the student's own behaviour. For Mary, it was a culturally mediated event. She broke the social rule of school where teachers are supposed to support the disciplinary procedures of their colleague's especially the administration. Eventually this child was able to return to our school. When they were told that the reason their son could be sent away was because of where they lived, they did something unexpected and moved into the school catchment area. When he returned, Mary wondered aloud to Brian what would happen now if this student broke a rule. He is a more powerful being now, Mary asserted. Coming back to our school would be a second chance to integrate into the school culture. His renewed presence critiqued the system that sent him away in the first place.

\subsection{Thinking about the trickster and the suspicious students}

Another VENN that Brian and I constructed revealed a mutual plotline for instantiating efficacy in us, each other, our new teacher mentees and, most of all, our students. These overlapping targets for efficacy produced the VENN. The most important story from this plotline dealt with a student teacher that Mary had taught at the university. This student teacher came in to Brian's class to help during the time when he ran a study skills class for Special Education students. The class was designed to help students with their homework, provide additional instruction, and assist in keeping track of their work and being accountable for their performance. Brian was not in charge of this student teacher, but she asked to spend time in his class having previously been in a group that Brian had conducted based on a curriculum project at the university. After several days, Brian realised that when he was there with the student teacher during class, the students preferred to come to him for assistance. In the interest of building the student teacher's efficacy for helping and the children's efficacy for receiving assistance from a wide variety of people, he opted to leave the student teacher in charge and do his record keeping at another location.

Unaware of these circumstances, Mary entered Brian's classroom to return some books she had borrowed. When Brian's students saw her, several left their desks and came to ask her for help with their assignments. When she suggested to the children that they should ask their teacher, meaning the student teacher, one expressed concern that she would not know how to help them. Mary explained that she knew this woman well and, in fact, she had been her teacher and Brian had worked with her. Mary assured the students that the student teacher was perfectly competent. The children reasoned that if Mary had taught the student teacher, then she must know everything that Mary knows, and they began to engage with her. We wanted the children to work with the student teacher and we both understood why they might be reluctant to do so. We also understood why the student teacher might be reluctant to engage with the students when they seem to be sending her signals that she is incompetent. Instead of adhering to the rule of school where adults punish or silence the children for being disobedient and even disrespectful to a teacher, Mary and Brian tried to find ways to acknowledge the students' concern and defend the student teacher. We learned from this story that instead of asking teachers who are early in their careers to be advocates, that instead it is they who often need advocates, not just with the administration, but also with the children themselves. Mary's action was not an act of permission to advocate for students, as Norquay \& Robertson-Baghel (2011) suggest should occur in schools. Instead, Mary gave permission to the students to trust the student teacher, and vicariously to the student teacher that she should trust herself. She got a second chance, a renewed opportunity-to work with the students in ways that would instantiate her teacher identity because of Brian's separation from the students and Mary's effort to reposition the student teacher in the eyes of the children. 
It is also worth noting that for beginning teachers, advocates are more efficacious if they know those burgeoning teachers and the children well. A university supervisor may not have been able to disrupt the children's plotline about the student teacher. Instead, many supervisors may have focused on trying to assuage the feelings of the student teacher while convincing her to be more assertive in her interactions with the children. Such an act would have been a summons to advocate using the definition around student learning that Athanases \& Martin (2006) call for.

\subsection{Thinking about the trickster(s) present (and absent) at the soccer game}

The final plotline that emerged from our VENNs was one of shared social capital (Putnam 2001). We have the impression that when young people work with one of us, they believe they are working with both of us. In the previous example with the student teacher, this plotline is revealed, as the students were more interested in soliciting assistance from Mary than the student teacher, even though they are not assigned to her as students. The children's actions suggested to them that Mary's help would be the same as Brian's. The students in our school sometimes employ strategic interactions to exploit this potential plotline. One time in particular, one of Mary's students brought a relative to play indoor soccer after school where Brian was the supervisor. Although Brian did not typically allow students who did not attend our school to play, he relied on the reputation of the student he knew as a responsible person and allowed the relative to stay. When the relative tried to hurt another student, however, Brian growled at him and both boys left.

Later that evening, Brian explained to Mary that he was upset with his own judgement to let the boy stay and with his loss of temper, but he was not angry with her student. Later on, the student approached Mary to explain that he was embarrassed that his relative had caused a problem and he understood why Brian had been upset. Mary reported that Brian did not blame him for the incident and the student resumed playing soccer after school. He no longer brought guests. Both Brian and the student came to Mary to apologise to each other, instead of directly interacting. They also both granted Mary agency to speak in their behalf to repair what both perceived to be damage to their relationship. Although they were tragically separated from each other, Brian and the child made valiant efforts to repair their relationship using indirect methods. The comedic device of substitution operated in this narrative as the child and his cousin traded places in the aftermath of the separation (it should have been that boy who felt sorry) and Brian and Mary traded places to bring about a reunion. All three of us disregarded social norms of defending friends and spouses, of never admitting wrongdoing, and of complete and total avoidance after unsavoury incidences by communicating — albeit indirectly.

In this story, Brian felt he needed to protect a large group of children and so he risked offending one child. In the moment where he was harshly reminding the young person of the rules, he was meeting the needs of the rest of the students to be safe, but he was not meeting the need of the aggressive student to be dealt with in a non-aggressive way. This incident highlights the tension that arises from Howe's (1986) definition of advocacy. There are also questions about whether the children Brian was protecting felt safe in the moment that they were witnessing Brian correcting the behaviour of the boy who was playing dangerously.

Finally, this incident speaks to the emotionality that is potentially present in many moments of advocacy. In that moment, Brian was not worried about tenure or his social position with the children or his colleagues. Even afterward, he worried about what the offending boy's relative at the school thought more than what anyone else in the school did, including me. He saw injustice and he worked to correct it swiftly, albeit harshly to some. We wonder about the issue of 
emotional charge in advocacy and how it seems to us that sometimes the fastest way to enact advocacy is in a moment of swift emotional reaction instead of a contemplative, deliberative one. When he acted quickly with the emotional force of his beliefs at the front of his behaviour, Brian ran the risk of marginalising himself from another person; in this case, it was a child. In another incident, it may have been parents, colleagues, administration, or the community. In the first story in this paper about the student who was sent away from school, both of us had moments of frustration, but our relationship prevented us from being separated from one another so we did not need to seek mediation in the aftermath. However, it is very likely that we engaged in a process of healing that neither of us noticed.

\section{Discussing the implications of reframing advocates as comedic tricksters}

The integration of comedy was necessary, according to Frye (1957) because it paved the way for the achievement of paradise. The opposite of paradise is purgatory, which is the unfortunate place where literary heroes end up if they fall into tragedy rather than making a comedic turn. The quest for any hero is to achieve paradise through comedic integration and avoid the separation and alienation of tragedy.

Using our stories, we were able to illustrate shared and individual efficacy, which for us meant that advocacy in schools is about sharing the responsibility for advocacy. For us as a married couple, it was easy to see that the nature of our personal relationship allowed us to share advocacy. However, we wonder if we are communicating to our teacher candidates and novice teacher mentees that they should also engage in a similar metanarrative of sharing advocacy responsibilities with colleagues with whom they have only professional relationships.

Due to their novice status, not only is it improbable that they have existing relationships from which they can immediately share responsibility, but they may not possess the skills for recognising or even building such relationships while they are attempting to attend to the procedural demands of lesson planning and classroom management. Although we see the classroom curriculum and management as ground zero for advocacy (Athanases \& Martin 2006), a novice teacher might not be able to intentionally use these for advocacy without careful mentoring, causing advocacy to collapse under the weight of the school landscape (Athanases \& Oliveira 2007). The lesson that we learn from looking at advocates as comedic tricksters is that they use keen understandings of their communities to hold a mirror up that reveals hypocrisy. New teachers, in most cases, lack those nuanced understandings and so they are less able to reveal a community to itself.

The school landscape, while weighty enough with what can be seen, may also have elements that are unseen under most circumstances. Hamel \& Jaasko-Fisher (2011) proposed that a type of Marxist hidden labour existed for mentors of student teachers. If the hidden labour hypothesis is correct, our efforts to advocate represent a hidden labour that is not currently on the research on neither the mentoring, nor the advocacy landscape. The fact that this work is done invisibly supports our interpretation of them as acts of tricksters. It is a trickster who does his or her work invisibly initially while the effects of the hidden work are seen only after the denouement. We are both people who work both intentionally and incidentally with student teachers and new colleagues in our school and people whose works of advocacy are often so micro-interactional (Cummins 2000) and so spontaneous that they would not be easily accounted for without serious

pause and reflection. Inexperienced teachers in need of constant hidden labour in other forms of mentoring support are surely not positioned well to notice their efforts at advocacy, judge the 
efficacy of those efforts, and accurately determine the nature and intensity of pressure not to advocate. They may not have enough understanding of what the social rules of the schools are in order to strategically break them in behalf of students.

If we continue to tell stories of advocacy to the teacher candidates in our classes at the university, we must also unpack the story to help the teacher candidates and novice teacher mentees see the ways in which we use concepts like curriculum and classroom management as instruments of advocacy. We also wondered if we could use the unpacking of stories to demonstrate how relationships might be built on a school landscape so that a meta-narrative of shared responsibility for advocacy can emerge for them.

For practitioners, part of the work of advocacy is deciding what actions to engage in to improve the educational experiences of students. The story of the visiting student who was expelled illustrates the complexity of meeting the needs of the school as well as individual students. In addition, multiple levels of intervention constitute advocacy. Sometimes, advocacy might mean not intervening at all, or intervening minimally as Mary tried to do with the student teacher working in Brian's classroom. Other times, it might mean heavily intervening, as when Brian and Mary's student granted her the agency to help repair a relationship after a negative incident during after school soccer. Interpreting our stories has caused us to wonder about the ways in which our understandings about advocacy could lead to deeper understandings about the ways in which shared and separate advocacy, efficacy, and social capital can be mobilised to build community in a school while still honouring the multiplicity of perspectives on a school landscape.

\section{References}

Athanases, S. \& Martin, K.J. (2006). 'Learning to advocate for educational equity in a teacher credential programme'. Teaching and Teacher Education 22 (6), pp. 627-646.

Athanases, S. \& Oliveira, L.C. (2007). 'Conviction, confrontation, and risk in new teachers' advocating for equity'. Teaching Education 18 (2), pp. 123-136.

Baquedano-López, P., Alexander, R. A. \& Hernandez, S. J. (2013). 'Equity issues in parental and community involvement in schools: What teacher educators need to know'. Review of Research in Education 37 (1), pp. 149-182.

Bartolomé, L. I. (2004). 'Critical pedagogy and teacher education: Radicalising prospective teachers'. Teacher Education Quarterly 31 (1), pp. 97-122.

Buendía, D. (2000). 'Power and possibility: The construction of a pedagogical practice'. Teaching and Teacher Education 16 (4), pp. 147-163.

Brophy, J. \& Good, T. L. (1994). Looking in Classrooms. New York, NY: Harper Collins.

Catapano, S. (2006). 'Teaching in urban schools: Mentoring pre-service teachers to apply advocacy strategies'. Mentoring \& Tutoring 14 (1), pp. 81-96.

Clandinin, D. J. \& Connelly, F. M. (1990). 'Stories of experience in narrative inquiry'. Educational Researcher 19 (5), pp. 2-14.

Clandinin, D. J. \& Connelly, F. M. (1995). Teachers' Professional Knowledge Landscapes. New York: Teachers College Press.

Clandinin, D. J. \& Connelly, F. M. (2000). Narrative Inquiry: Experience and Story in Qualitative Research. Thousand Oaks, CA: Jossey Bass.

Clandinin, D., Pushor, D. \& Murray-Orr, A. (2007). 'Navigating sites for narrative inquiry'. Journal of Teacher Education 58 (1), pp. 21-35. 
Cummins, J. (2000). Language, Power and Pedagogy: Bilingual Children Caught in the Crossfire. Toronto: Multilingual Matters.

Engeström, Y. (2001). 'Expansive learning at work: Toward an activity theoretical reconceptualisation'. Journal of Education and Work 14 (1), pp. 133-156.

Erikson, E. H. (1994). Identity: Youth and Crisis. New York: WW Norton Press.

Fisher, W. R. (1984). 'Narration as a human communication paradigm: The case of public moral argument'. Communications Monographs 51 (1), pp. 1-22.

Frye, N. (2002). 'The argument of comedy', in Richardson, B. (ed.), Narrative Dynamics: Essays on Time, Plot, Closure, and Frames, Columbus: Ohio State University Press, pp. 102-109.

Frye, N. (1957). Anatomy of Criticism: Four Essays. Princeton: Princeton University Press.

Hamel, F. L. \& Jassko-Fisher, H.A. (2011). 'Hidden labour in the mentoring of pre-service teachers: Notes from a mentor teacher advisory council'. Teaching and Teacher Education 22 (2), pp. 434-432.

Hanrahan, J. K. (2003). 'Truth in action: Revitalising classical rhetoric as a tool for teaching oral advocacy in American law schools'. BYU Education \& Law Journal 1, pp. 299-338.

Hansen, G.P. (2001). The Trickster and the Paranormal. Philadelphia, PA: Xlibris.

Howe, H. (1986). 'The prospect for children in the United States'. Phi Delta Kappan 68 (4), pp. 191-196.

Kelly, T. E. (1986). 'Discussing controversial issues: Four perspectives on the teacher's role'. Theory \& Research in Social Education 14 (2), pp. 113-138.

Loughran, J. \& Northfield, J. (1996). Opening the Classroom Door: Teacher, Researcher, Learner. London: Falmer.

Norquay, N. \& Robertson-Baghel, M. (2011). 'Embracing advocacy: How visible minority and dominant group teachers take up issues of equity'. Brock Education 21 (2), pp. 65-84.

Priyadharshini, E. (2012). 'Thinking with trickster: Sporadic illuminations for educational research'. Cambridge Journal of Education 42 (4), pp. 547-561.

Putnam, R. D. (2001). Bowling Alone: The Collapse and Revival of American Community. New York, NY: Simon and Schuster.

Rice, M. (2009). 'A narrative inquiry self-study of advocacy by an educator with multiple roles'. Brock Education 18 (2), pp. 16-28.

Roberts, J. L. \& Siegle, D. (2012). 'If not you - who? Teachers as advocates'. Gifted Child Today 35 (1), pp. 58-61.

Vevea, B. (2010). 'School funds don't match teacher layoffs'. September 23. Journal Sentinel. Available online: http://www.jsonline.com/news/education/103590969.html [Accessed on 8 April 2014].

Walker, D. (2010). 'Education reform: It's up to us'. August/September. NEA Today. Available online: http://www.nea.org/home/40372.htm [Accessed on 8 April 2014].

Wilson, W. (1990). 'In praise of ourselves: Stories to tell'. BYU Studies 30 (1), pp. 5-34.

Wyatt, S. (2005). 'Awakening the trickster'. Paper presented at the First International Congress of Qualitative Inquiry. University of Illinois at Urbana-Champaign, Illinois, 5-7 May. Available online: http://www.iiqi.org/C4QI/httpdocs/qi2005/papers/wyatt3.pdf [Accessed on 18 August 2015].

Zeichner, K. (2003). 'The adequacies and inadequacies of three current strategies to recruit, prepare, and retain the best teachers for all students'. The Teachers College Record 105 (3), pp. 490-519. 